\title{
Assessment of metals bioavailability to vegetables under field conditions using DGT, single extractions and multivariate statistics
}

\author{
Marin Senila*, Erika Andrea Levei and Lacrimioara Ramona Senila
}

\begin{abstract}
Background: The metals bioavailability in soils is commonly assessed by chemical extractions; however a generally accepted method is not yet established. In this study, the effectiveness of Diffusive Gradients in Thin-films (DGT) technique and single extractions in the assessment of metals bioaccumulation in vegetables, and the influence of soil parameters on phytoavailability were evaluated using multivariate statistics. Soil and plants grown in vegetable gardens from mining-affected rural areas, NW Romania, were collected and analysed.

Results: Pseudo-total metal content of $\mathrm{Cu}, \mathrm{Zn}$ and $\mathrm{Cd}$ in soil ranged between $17.3-146 \mathrm{mg} \mathrm{kg}^{-1}, 141-833 \mathrm{mg} \mathrm{kg}^{-1}$ and $0.15-2.05 \mathrm{mg} \mathrm{kg}^{-1}$, respectively, showing enriched contents of these elements. High degrees of metals extractability in $1 \mathrm{M} \mathrm{HCl}$ and even in $1 \mathrm{M} \mathrm{NH}_{4} \mathrm{Cl}$ were observed. Despite the relatively high total metal concentrations in soil, those found in vegetables were comparable to values typically reported for agricultural crops, probably due to the low concentrations of metals in soil solution $\left(C_{\text {soln }}\right)$ and low effective concentrations $\left(C_{E}\right)$, assessed by DGT technique. Among the analysed vegetables, the highest metal concentrations were found in carrots roots. By applying multivariate statistics, it was found that $\mathrm{C}_{\mathrm{E}} \mathrm{C}_{\text {soln }}$ and extraction in $1 \mathrm{M} \mathrm{NH}_{4} \mathrm{Cl}$, were better predictors for metals bioavailability than the acid extractions applied in this study. Copper transfer to vegetables was strongly influenced by soil organic carbon (OC) and cation exchange capacity (CEC), while pH had a higher influence on $\mathrm{Cd}$ transfer from soil to plants.
\end{abstract}

Conclusions: The results showed that DGT can be used for general evaluation of the risks associated to soil contamination with $\mathrm{Cu}, \mathrm{Zn}$ and $\mathrm{Cd}$ in field conditions. Although quantitative information on metals transfer from soil to vegetables was not observed.

Keywords: DGT, Effective concentration, Chemical extraction, Metal, Vegetable, Multivariate statistics

\section{Background}

The concentrations of toxic metals in soils have continuously increased as a result of anthropogenic activities through inputs mainly from mining, municipal wastes, road traffic or fuel burning. In addition to their toxicity, metals persist in soil for long times and have the capacity to be transferred into the food chain $[1,2]$ thus the assessment of their content in soil and the estimation of their transfer rates to vegetation are of great interest [3]. The soil quality guidelines are usually based on total metal content, although it is generally accepted that

\footnotetext{
* Correspondence: marin.senila@icia.ro

INCDO-INOE 2000, Research Institute for Analytical Instrumentation, ICIA, 67 Donath, 400293, Cluj-Napoca, Romania
}

total metal content include both bioavailable and nonbioavailable fractions [4]. The estimation of bioavailable metal fractions is, generally, based on single or sequential extraction procedures $[5,6]$, but these provide only a classification of metal fractions in the soil compartments. Additionally, in the pretreatment stage of these procedures, the physical-chemical equilibrium in soil may be affected [7]. The Diffusive Gradients in Thinfilms (DGT) is a promising tool in the assessment of bioavailable fraction of metals in soil. It was developed for measuring labile metal species in aqueous systems, $[8,9]$ but its applicability was also extended to sediments and soils. In soils, DGT mimic the uptake of metals by the plant roots because, like these, decrease metal concentrations in their vicinity and responds to
(C) Chemistry Central

(c) 2012 Senila et al.; licensee Chemistry Central Ltd. This is an Open Access article distributed under the terms of the Creative Commons Attribution License (http://creativecommons.org/licenses/by/2.0), which permits unrestricted use, distribution, and reproduction in any medium, provided the original work is properly cited. 
metals re-supplied from soil solution and solid phase. Good correlations between available fraction of some metals in soils measured by DGT and their concentration in plants, after pot experiments, were reported [10-12].

Although DGT technique is expected to be superior to the conventional extraction techniques its effectiveness in assessing metals transfer to plants is still under debate. Moreover, there are only a few papers that present data on DGT method use for assessment of metals availability to plants, especially in field trials. However, DGT does not account the processes from rhizosphere, such as root-induced $\mathrm{pH}$ changes and exudation of metal complexing compounds that influence metal bioavailability to plants [13-15]. Consequently, to date, an universally accepted procedure for metals bioavailability prediction does not exist and the development and validation of such methods that allows the estimation of the risks posed by the occurrence of toxic metals in soils are necessary [15].

The aim of this study was to assess the metals bioavailability in garden soils from rural areas affected by mining activities using DGT technique and single extractions, to correlate the potentially bioavailable metals fractions with the soil properties and to study the effectiveness of different methods to predict metals uptake in edible parts of several vegetable species. Multivariate statistical approaches were used to reveal the relationships between soil properties, metals concentrations in soil, and their bioaccumulation in vegetables.

\section{Results and discussion}

Pseudo-total metal contents and characteristics of soils

The general characteristics of the soils are presented in Table 1. Soil $\mathrm{pH}$ values were in the neutral range (6.77.8), while the soil organic carbon (OC) ranged between $1.5-5.4 \%$ showing the different fertilization degree of soils. The cation exchange capacity (CEC) values were in the range of $13.1-25.7 \mathrm{meq} 100 \mathrm{~g}^{-1}$ with average value of 19.7 meq $100 \mathrm{~g}^{-1}$. The pseudo-total content of $\mathrm{Cu}$ ranged between 17.3 and $146 \mathrm{mg} \mathrm{kg}^{-1}$ dry weight $(\mathrm{dw})$ with the average value below the alert level $\left(100 \mathrm{mg} \mathrm{kg}^{-1}\right)$ for soils from sensitive areas established by Romanian legislation (MO 756:1997). Nevertheless, in four sampling points from BM, one sampling point from SA and one from RC this value was exceeded. For $\mathrm{Zn}$, the pseudo-total content was in the range of $141-833 \mathrm{mg} \mathrm{kg}^{-1} \mathrm{dw}$, with the average content exceeding the alert level. Additionally, in $20 \%$ of the sampling points the intervention level for $\mathrm{Zn}$ was exceeded. The content of $\mathrm{Cd}$ in all analysed samples were below the alert level, however $33 \%$ of soil samples exceeded the worldwide range of $\mathrm{Cd}$ in soils (0.06-1.1 mg kg-1 mean of $\left.0.53 \mathrm{mg} \mathrm{kg}^{-1}\right)$ [16], showing an enrichment of soil Cd content. The obtained results are confirmed by previous studies that reported similar contamination levels with metals of soils from the Baia Mare area $[17,18]$.

\section{Chemical single extraction procedures for metals bioavailability prediction}

Table 2 shows the ranges and the averages of extractable heavy metal contents obtained by $1 \mathrm{M} \mathrm{HCl}$ and $1 \mathrm{M} \mathrm{NH}_{4} \mathrm{Cl}$ extractions. Compared to the pseudo-total metal contents, the average percentage of the $\mathrm{HCl}$ extracted metal fractions were relatively high $(64 \% \mathrm{Cu}, 32 \% \mathrm{Zn}$ and $75 \% \mathrm{Cd})$. It is recognized that $1 \mathrm{M} \mathrm{HCl}$ not attack the silicates and thus the amounts of metals measured by this extraction procedure estimates better the bioavailable fraction than the total metals content [19]. Significant positive relationship between pseudo-total metal and $1 \mathrm{M} \mathrm{HCl}$ extractable metal contents were obtained by linear regression, with regression coefficients $(\mathrm{r})$ of 0.94 for $\mathrm{Cu}, 0.96$ for $\mathrm{Zn}$ and 0.95 for $\mathrm{Cd}$, respectively. As expected, the contents of metals extracted by $\mathrm{NH}_{4} \mathrm{Cl}$ were lower than those extracted by $\mathrm{HCl}$, the average percent of extracted $\mathrm{Cd}$ was $53 \%$, while for $\mathrm{Cu}$ and $\mathrm{Zn}$ were $24 \%$ and $16 \%$, respectively.

Table 1 General characteristics of soils collected from the study area

\begin{tabular}{|c|c|c|c|c|c|c|c|}
\hline \multirow[t]{2}{*}{ Sites } & & \multirow[t]{2}{*}{$\mathrm{pH}$} & \multirow{2}{*}{$\begin{array}{l}\text { OC } \\
\text { (\%) }\end{array}$} & \multirow[t]{2}{*}{ CEC (meq $100 \mathrm{~g}^{-1}$ ) } & \multicolumn{3}{|c|}{ Total concentration $\left(\mathrm{mg} \mathrm{kg}^{-1} \mathrm{dw}\right)$} \\
\hline & & & & & $\overline{\mathrm{Cu}}$ & $\mathrm{Zn}$ & $\mathrm{Cd}$ \\
\hline \multirow[t]{2}{*}{$\mathrm{BM}$} & Mean & 7.1 & 3.2 & 20.0 & 79.8 & 550 & 1.29 \\
\hline & Range & $6.7-7.5$ & $1.9-4.8$ & $13.1-25.7$ & 29.1-122 & $222-833$ & $0.39-2.05$ \\
\hline \multirow[t]{2}{*}{$\mathrm{RC}$} & Mean & 7.2 & 2.9 & 18.6 & 48.2 & 393 & 0.85 \\
\hline & Range & $6.8-7.6$ & $1.5-4.0$ & $14.5-22.1$ & $22.8-106$ & $178-660$ & $0.43-1.44$ \\
\hline \multirow[t]{2}{*}{ SA } & Mean & 7.3 & 4.2 & 20.6 & 50.9 & 394 & 0.56 \\
\hline & Range & $6.9-7.8$ & $3.3-5.4$ & $17.8-24.1$ & $17.3-146$ & $141-491$ & $0.15-1.34$ \\
\hline$A L^{*}$ & & - & - & - & 100 & 300 & 3 \\
\hline $\mathrm{IL}^{* *}$ & & - & - & - & 200 & 600 & 5 \\
\hline
\end{tabular}

* AL-alert level for soil in sensitive (residential and agricultural) areas (Ministerial Order 756:1997).

** IL- intervention level for soil in sensitive (residential and agricultural) areas. 
Table 2 The extractable metal contents in diluted acid and in neutral salt solution

\begin{tabular}{|c|c|c|c|c|c|c|c|}
\hline \multirow[t]{2}{*}{ Sites } & & \multicolumn{3}{|c|}{$1 \mathrm{M} \mathrm{HCl}\left(\mathrm{mg} \mathrm{kg}^{-1} \mathrm{dw}\right)$} & \multicolumn{3}{|c|}{$1 \mathrm{M} \mathrm{NH}_{4} \mathrm{Cl}\left(\mathrm{mg} \mathrm{kg}^{-1} \mathrm{dw}\right)$} \\
\hline & & $\mathrm{Cu}$ & $\mathrm{Zn}$ & $\mathrm{Cd}$ & $\mathrm{Cu}$ & $\mathrm{Zn}$ & $\mathrm{Cd}$ \\
\hline \multirow[t]{2}{*}{ BM } & Mean & 40.0 & 176 & 0.95 & 11.7 & 68.6 & 0.76 \\
\hline & Range & $14.7-73.3$ & $85.0-253$ & $0.34-1.56$ & $7.01-18.0$ & $32.1-124$ & $0.28-1.20$ \\
\hline \multirow[t]{2}{*}{$\mathrm{RC}$} & Mean & 33.4 & 117 & 0.64 & 9.55 & 59.5 & 0.38 \\
\hline & Range & $11.8-46.8$ & $52.6-166$ & $0.40-1.06$ & $6.31-17.2$ & $31.0-102$ & $0.21-0.78$ \\
\hline \multirow[t]{2}{*}{ SA } & Mean & 35.5 & 119 & 0.36 & 13.4 & 64.8 & 0.24 \\
\hline & Range & $13.4-84.2$ & $43.1-145$ & $0.13-0.83$ & $8.03-22.0$ & 29.1-109 & $0.09-0.55$ \\
\hline
\end{tabular}

Significant positive correlations were found between the pseudo-total metal contents and the metals extracted in $\mathrm{NH}_{4} \mathrm{Cl}: \mathrm{Cu}(\mathrm{r}=0.55)$ and $\mathrm{Cd}(\mathrm{r}=0.72)$, while for $\mathrm{Zn}$, the correlation was not significant. Generally, the percent of metals extracted both in $\mathrm{HCl}$ and $\mathrm{NH}_{4} \mathrm{Cl}$ were in good agreement with the extractability ranges reported by Kashem et al. [19] for contaminated soils, except for $\mathrm{Cu}$, that in our study was highly extracted by $\mathrm{NH}_{4} \mathrm{Cl}$.

Contents of metals in soil solution and measured by DGT Table 3 shows the metals concentrations in soil solutions $\left(C_{\text {soln }}\right)$ obtained by centrifugation of the soil slurries used for DGT deployments and metal concentrations in the eluents of the DGT resins $\left(C_{D G T}\right)$. The amounts of metals measured as $C_{\text {soln }}$ and $C_{D G T}$ were considerably lower than those extracted in $\mathrm{HCl}$ and $\mathrm{NH}_{4} \mathrm{Cl}$. In soil solution, concentrations of $\mathrm{Zn}$ were found in the range of 31-67 $\mu \mathrm{g} \mathrm{L}^{-1}$ (average of $47 \mu \mathrm{g} \mathrm{L}^{-1}$ ), $\mathrm{Cu}$ in the range of 25-66 $\mu \mathrm{g} \mathrm{L}^{-1}$ (average of $40 \mu \mathrm{g} \mathrm{L}^{-1}$ ), while $\mathrm{Cd}$ was one order of magnitude lower than $\mathrm{Cu}$ and $\mathrm{Zn}$, ranging between $0.24-1.4 \mu \mathrm{g} \mathrm{L}^{-1}$ (average of $0.67 \mu \mathrm{g} \mathrm{L}^{-1}$ ). For $\mathrm{Zn}$ and $\mathrm{Cd}$ significant positive correlation was found between $\mathrm{C}_{\mathrm{DGT}}$ and $\mathrm{C}_{\text {soln }}$, while $\mathrm{Cu} C_{D G T}$ was weakly related to $C_{\text {soln }}$. The $\mathrm{R}$ ratio $C_{D G T} / C_{\text {soln }}(0<\mathrm{R}<1)$ indicates the capacity of the soil solid phase to resupply the soil solution with metals. When $\mathrm{R}>0.95$, the metal is present as mobile and kinetically labile species in the solid phase and the capacity of the solid phase to resupply the pore water is high. An $\mathrm{R}$ value approaching 0 suggests very limited or no metal resupply from the solid phase [20]. The $\mathrm{R}$ ratios for $\mathrm{Zn}, \mathrm{Cd}$, and $\mathrm{Cu}$ ranged between 0.39 $0.74,0.24-0.84$ and $0.20-0.63$, respectively, indicating an intermediate case for metal resupply from the solid phase. Also, it seems that $\mathrm{Zn}$ and $\mathrm{Cd}$ are resupplied more easily than $\mathrm{Cu}$ from the soil solid phase.

Table 4 presents the values of particle concentration (Pc) of soils in each sampling point, the $R_{\text {diff }}$ values calculated using 2D DIFS model and the effective concentration $\left(C_{E}\right)$ calculated as the ratio between $C_{\mathrm{DGT}}$ and $R_{\text {diff. }}$ Over-all, homogenous values of $P_{c}$ were observed for soils collected in gardens from the same village, with the lowest values in SA. The average values of effective
Table 3 Contents of metals in soil solutions $\left(C_{\text {soln }}\right)$ and metals measured using DGT technique $\left(C_{D G T}\right)$ (Means $\pm S D$, $\mathrm{n}=3$ )

\begin{tabular}{|c|c|c|c|c|c|c|}
\hline \multirow[t]{2}{*}{ Sites } & \multicolumn{3}{|c|}{$C_{\text {soln }}\left(\mu \mathrm{g} \mathrm{L}^{-1}\right)$} & \multicolumn{3}{|c|}{$C_{D G T}\left(\mu g^{-1}\right)$} \\
\hline & $\mathrm{Cu}$ & $\mathrm{Zn}$ & $\mathrm{Cd}$ & $\mathrm{Cu}$ & $\mathrm{Zn}$ & $\mathrm{Cd}$ \\
\hline 1 & $36 \pm 2.3$ & $31 \pm 0.5$ & $1.0 \pm 0.12$ & $3 \pm 1.6$ & $15 \pm 1.6$ & $0.51 \pm 0.08$ \\
\hline 2 & \pm 2.0 & $53 \pm 0.7$ & $1.4 \pm 0.16$ & $13 \pm 1.8$ & $36 \pm 2.8$ & $0.65 \pm 0.07$ \\
\hline 3 & \pm 3.3 & $34 \pm 0.3$ & $0.98 \pm 0.09$ & $8.3 \pm 0.9$ & $19 \pm 1.5$ & $0.53 \pm 0.09$ \\
\hline 1 & +31 & $47 \pm 0.5$ & $0.68 \pm 0.11$ & $0 \pm 1.4$ & $28 \pm 1.4$ & $0.48 \pm 0.07$ \\
\hline 3 & $3 \pm 2.6$ & $55 \pm 0.9$ & $0.64 \pm 0.15$ & $10 \pm 0.8$ & $28 \pm 2.1$ & $3 \pm 0.05$ \\
\hline 6 & 5 & 3 & 7 & .3 & $33 \pm 2.4$ & \pm 0.04 \\
\hline 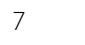 & \pm 2.0 & $64 \pm 1.0$ & 7 & $5.0 \pm 0.7$ & 31 & \pm 0.06 \\
\hline 8 & $5+32$ & $67 \pm 1.1$ & 1 & .9 & $43 \pm 2.7$ & $8 \pm 0.07$ \\
\hline 0 & 6 & $50 \pm$ & $1.0 \pm 0.08$ & .6 & 29 & 10 \\
\hline 10 & $32 \pm 3.1$ & $35 \pm 0.7$ & $1.3 \pm 0.13$ & $6.6 \pm 0.7$ & $25 \pm 1.9$ & $0.76 \pm 0.09$ \\
\hline 1 & $1+28$ & 6 & 0 & 2 & $42 \pm 2.5$ & .03 \\
\hline 2 & $5 \pm 3.9$ & $58 \pm 1.3$ & $0.29 \pm 0.04$ & $18 \pm 1.5$ & $28 \pm 2.3$ & $0.16 \pm 0.03$ \\
\hline 13 & $3 \pm 2.5$ & $46 \pm 1.5$ & 0.2 & $8.4 \pm 0.7$ & $21=$ & $0.19 \pm 0.02$ \\
\hline 4 & \pm 2.6 & $56 \pm 0.8$ & $1.3 \pm 0.07$ & $16 \pm$ & $33=$ & .02 \\
\hline 15 & $36 \pm 1.8$ & $63 \pm 1.6$ & $0.56 \pm 0.05$ & $23 \pm 2.1$ & $43 \pm 2.2$ & $0.15 \pm 0.03$ \\
\hline 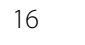 & $42 \pm 1.9$ & 3 & ( & 0 & $14 \pm 1.5$ & 准 \\
\hline 17 & $31 \pm 2.2$ & $38 \pm 1.6$ & $0.42 \pm 0.05$ & $12 \pm 1.1$ & $20 \pm 1.7$ & $0.33 \pm 0.03$ \\
\hline 18 & 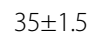 & 41 & $+0,0$ & 9 & 20 & $036+003$ \\
\hline 9 & \pm 1 & $30 \pm$ & 0 & 9 & 10 & 02 \\
\hline 20 & $40 \pm 2.0$ & $31 \pm 0.2$ & $0.38 \pm 0.08$ & $16 \pm 1.7$ & $23 \pm 1.8$ & $0.12 \pm 0.03$ \\
\hline 1 & 2 & $49 \pm 0.4$ & $160+\frac{1}{2}$ & 19 & 28 & ( \\
\hline 22 & $31 \pm 1.6$ & $50 \pm 0.4$ & $0.30 \pm 0.02$ & $10 \pm 0.8$ & $30 \pm 2.7$ & $0.17 \pm 0.03$ \\
\hline 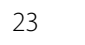 & $41 \pm 2.9$ & $31 \pm 0.6$ & $0.65 \pm 0.08$ & $16 \pm 1.3$ & $15 \pm$ & $0.18 \pm 0.03$ \\
\hline 24 & $28 \pm 1.3$ & $37 \pm 0.8$ & $0.38 \pm 0.07$ & $12 \pm 1.0$ & $20 \pm 1.5$ & $0.28 \pm 0.07$ \\
\hline 25 & $39 \pm 1.5$ & $47 \pm 1.0$ & $0.42 \pm$ & $13 \pm 1.0$ & $19 \pm 1.9$ & $0.14 \pm 0.03$ \\
\hline 26 & $36 \pm 1.8$ & $49 \pm 0.9$ & $0.28 \pm 0.06$ & $14 \pm 1.5$ & $24 \pm 1.8$ & $0.19 \pm 0.05$ \\
\hline 27 & $44 \pm 2.6$ & $49 \pm 0.6$ & $0.73 \pm 0.07$ & $9.3 \pm 1.6$ & $22 \pm 1.6$ & $0.30 \pm 0.05$ \\
\hline 28 & $4< \pm<.0$ & $53 \pm 1.5$ & $0.99 \pm 0.05$ & $10 \pm 0.9$ & $21 \pm 1.8$ & (6. \\
\hline 29 & $58 \pm 2.8$ & $52 \pm 1.4$ & $0.76 \pm 0.08$ & $17 \pm 1.8$ & $34 \pm 2.2$ & $0.40 \pm 0.05$ \\
\hline 30 & $52 \pm 1.6$ & $36 \pm 1.1$ & $0.29 \pm 0.05$ & $20 \pm 1.9$ & $23 \pm 2.9$ & $0.17 \pm 0.03$ \\
\hline
\end{tabular}

Note. BM: 1-10; SA: 11-20; RC: 21-30. 
Table 4 Particle concentation $\left(P_{c}\right), R_{\text {diff }}$ calculated by $2 D$ DIFS model and bioavailable metals estimated by determination of effective concentration $\left(C_{E}\right)$

\begin{tabular}{|c|c|c|c|c|c|c|c|}
\hline \multirow{2}{*}{$\begin{array}{l}\text { Sample } \\
\text { sites }\end{array}$} & \multirow[t]{2}{*}{$P_{c}\left(g \mathrm{~cm}^{-3}\right)$} & \multicolumn{3}{|c|}{$R_{\text {diff }}$} & \multicolumn{3}{|c|}{$C_{E}\left(\mu \mathrm{g} \mathrm{L}^{-1}\right)$} \\
\hline & & $\mathrm{Cu}$ & $\mathrm{Zn}$ & $C d$ & $\mathrm{Cu}$ & $\mathrm{Zn}$ & $\mathrm{Cd}$ \\
\hline 1 & 4.11 & 0.0398 & 0.0407 & 0.0407 & 333 & 361 & 12.4 \\
\hline 2 & 4.25 & 0.0395 & 0.0404 & 0.0404 & 318 & 888 & 16.1 \\
\hline 3 & 4.00 & 0.0400 & 0.0410 & 0.0409 & 208 & 465 & 12.8 \\
\hline 4 & 4.38 & 0.0391 & 0.0400 & 0.0400 & 516 & 689 & 12.0 \\
\hline 5 & 4.55 & 0.0388 & 0.0397 & 0.0397 & 258 & 716 & 8.37 \\
\hline 6 & 4.36 & 0.0392 & 0.0401 & 0.0401 & 437 & 814 & 6.53 \\
\hline 7 & 4.22 & 0.0395 & 0.0404 & 0.0404 & 378 & 765 & 10.8 \\
\hline 8 & 4.01 & 0.0400 & 0.0410 & 0.0409 & 547 & 1050 & 11.8 \\
\hline 9 & 4.00 & 0.0400 & 0.0410 & 0.0409 & 126 & 710 & 7.10 \\
\hline 10 & 3.56 & 0.0412 & 0.0422 & 0.0422 & 161 & 603 & 18.0 \\
\hline 11 & 3.82 & 0.0406 & 0.0415 & 0.0415 & 357 & 1020 & 4.69 \\
\hline 12 & 3.66 & 0.0410 & 0.0419 & 0.0419 & 435 & 680 & 3.88 \\
\hline 13 & 3.89 & 0.0403 & 0.0412 & 0.0412 & 208 & 502 & 4.50 \\
\hline 14 & 3.16 & 0.0426 & 0.0436 & 0.0435 & 386 & 765 & 10.5 \\
\hline 15 & 4.02 & 0.0400 & 0.0410 & 0.0409 & 567 & 1050 & 3.67 \\
\hline 16 & 4.12 & 0.0398 & 0.0407 & 0.0407 & 345 & 348 & 3.06 \\
\hline 17 & 3.81 & 0.0406 & 0.0416 & 0.0415 & 292 & 470 & 7.90 \\
\hline 18 & 3.55 & 0.0412 & 0.0422 & 0.0422 & 298 & 482 & 8.51 \\
\hline 19 & 3.56 & 0.0412 & 0.0422 & 0.0422 & 482 & 391 & 1.84 \\
\hline 20 & 4.08 & 0.0399 & 0.0409 & 0.0408 & 412 & 560 & 2.86 \\
\hline 21 & 4.23 & 0.0395 & 0.0404 & 0.0404 & 316 & 686 & 5.92 \\
\hline 22 & 4.44 & 0.0389 & 0.0399 & 0.0398 & 263 & 765 & 4.29 \\
\hline 23 & 4.29 & 0.0393 & 0.0403 & 0.0402 & 412 & 381 & 4.49 \\
\hline 24 & 5.06 & 0.0377 & 0.0386 & 0.0385 & 314 & 523 & 7.14 \\
\hline 25 & 4.91 & 0.0380 & 0.0389 & 0.0388 & 335 & 498 & 3.68 \\
\hline 26 & 4.62 & 0.0387 & 0.0396 & 0.0395 & 371 & 594 & 4.69 \\
\hline 27 & 4.29 & 0.0393 & 0.0403 & 0.0402 & 237 & 558 & 7.55 \\
\hline 28 & 4.21 & 0.0395 & 0.0404 & 0.0404 & 261 & 524 & 9.60 \\
\hline 29 & 4.15 & 0.0396 & 0.0405 & 0.0405 & 422 & 827 & 9.82 \\
\hline 30 & 4.52 & 0.0388 & 0.0397 & 0.0397 & 520 & 579 & 4.29 \\
\hline
\end{tabular}

Note. BM: 1-10; SA: 11-20; RC: 21-30. concentration, $\mathrm{C}_{\mathrm{E}}$, decreased in the order: $\mathrm{Zn}>\mathrm{Cu}>\mathrm{Cd}$, similarly with that observed for soil solution. The measured $C_{E}$ was, in general, lower but with similar decreasing trend to that reported by Soriano-Disla et al. [12]. Also, $C_{E}$ values for $\mathrm{Cu}$ were comparable with those reported by Ruello et al. [21] for industrial contaminated soils.

\section{Metals concentrations in vegetables}

The food chain represents one of the main sources of human exposure to soil contamination through consumption of vegetables. In the Table 5 the concentrations of metals accumulated in the roots of vegetables are shown. Despite the relatively high total metal contents in garden soils, their concentration in roots were similar to metals concentrations typically found in agricultural crops (Cu: 4-15 mg kg-1 dw; Zn: $15-200 \mathrm{mg} \mathrm{kg}^{-1} \mathrm{dw}$; Cd: $0.2-0.8 \mathrm{mg} \mathrm{kg}^{-1} \mathrm{dw}$ ) [22], probably due to the low concentrations in soil pore water and low effective concentrations in soil. The highest metal concentrations were found in carrots, while in garlic and onion the concentrations were comparable. In vegetables from $\mathrm{BM}$ area the metals concentrations were higher than in those from RC and SA.

The averages of bioavailability factors $(B F s)$ calculated as the ratio between the pseudo-total metal content in the plant roots and in soils were $\mathrm{Cu} 0.086, \mathrm{Zn} 0.094$ and $\mathrm{Cd} 0.481$ for carrots, $\mathrm{Cu} 0.058, \mathrm{Zn} 0.076$ and $\mathrm{Cd} 0.372$ for onion, and $\mathrm{Cu} 0.063$, $\mathrm{Zn} 0.088$ and $\mathrm{Cd} 0.329$ for garlic, respectively. The $B F s$ followed the order: $\mathrm{Cd}>\mathrm{Zn}>\mathrm{Cu}$ reported in other studies [23,24]. Also, the $B F s$ were of the same order of magnitude with those obtained by Miclean et al. [25] for vegetables collected from Baia Mare area.

\section{Multivariate statistics}

Multivariate statistical approaches are considered very effective for the visualization of relationship between the variables of a multi-dimensional dataset [26], Principal Component Analysis (PCA) and Agglomerative Hierarchical Clustering (AHC) were used to study the specific behaviour of metals in soil plant system, taking into account their total and available contents in soil, accumulation in vegetable, and the soil properties $(\mathrm{pH}, \mathrm{OC}$,

Table 5 Metals in roots of vegetables collected from the study area

\begin{tabular}{|c|c|c|c|c|c|c|c|c|c|c|}
\hline \multirow[t]{2}{*}{ Sites } & & \multicolumn{3}{|c|}{ Carrot $\left(\mathrm{mg} \mathrm{kg}^{-1} \mathrm{dw}\right)$} & \multicolumn{3}{|c|}{ Onion $\left(\mathrm{mg} \mathrm{kg}^{-1} \mathrm{dw}\right)$} & \multicolumn{3}{|c|}{ Garlic (mg kg $\left.{ }^{-1} \mathrm{dw}\right)$} \\
\hline & & $\overline{\mathrm{Cu}}$ & $\mathrm{Zn}$ & $\mathrm{Cd}$ & $\mathrm{Cu}$ & $\mathrm{Zn}$ & $\mathrm{Cd}$ & $\mathrm{Cu}$ & $\mathrm{Zn}$ & $\mathrm{Cd}$ \\
\hline \multirow[t]{2}{*}{$\mathrm{BM}$} & Mean & 4.22 & 39.5 & 0.60 & 2.75 & 34.5 & 0.32 & 3.07 & 38.7 & 0.28 \\
\hline & Range & $2.41-7.32$ & $19.5-77.9$ & $0.27-0.92$ & $1.45-3.60$ & 21.7-57.6 & $0.17-0.59$ & $1.85-4.30$ & $25.6-64.5$ & $0.09-0.46$ \\
\hline \multirow[t]{2}{*}{$\mathrm{RC}$} & Mean & 3.39 & 33.8 & 0.28 & 2.51 & 24.9 & 0.16 & 2.68 & 29.0 & 0.22 \\
\hline & Range & $2.10-6.50$ & $21.7-48.6$ & $0.06-0.64$ & $2.05-3.20$ & $17.9-44.1$ & $0.05-0.27$ & $2.10-3.31$ & $17.8-46.5$ & $0.03-0.44$ \\
\hline \multirow[t]{2}{*}{ SA } & Mean & 4.29 & 32.3 & 0.12 & 2.68 & 27.9 & 0.17 & 2.68 & 33.3 & 0.14 \\
\hline & Range & $2.04-5.70$ & $19.9-64.3$ & $0.04-0.34$ & $1.81-3.51$ & $18.3-48.6$ & $0.05-0.42$ & $1.77-3.55$ & $21.7-53.6$ & $0.03-0.35$ \\
\hline
\end{tabular}


CEC). The varimax rotated factor loadings of principal components (PCs) are presented in Table 6. Five PC's with eigenvalues higher than 1 explains $78.2 \%$ of the system variance. The first PC exhibits $34.2 \%$ of the total variance with positive loadings on pseudo-total metal contents in soil and indicates the common sources of contamination with these metals, represented probably by the mining activities. This latent factor contains also the metals extracted in diluted strong acid showing the good correlations among the pseudo-total and $1 \mathrm{M} \mathrm{HCl}$ extractable metal contents. The significant positive loading of $\mathrm{Cd}$ extracted in $1 \mathrm{M} \mathrm{NH}_{4} \mathrm{Cl}$ from this $\mathrm{PC}$ can be explained by its high extractability in this solution.

The second latent factor, responsible for $18.5 \%$ of the total variance, shows the correlations between bioavailable

\section{Table 6 Varimax rotated factor loadings of experimental} variables

\begin{tabular}{|c|c|c|c|c|c|}
\hline Variable & PC1 & PC2 & PC3 & PC4 & PC5 \\
\hline $\mathrm{Cu} A R$ & 0.878 & 0.086 & 0.189 & 0.062 & 0.226 \\
\hline $\mathrm{Zn} A R$ & 0.843 & -0.018 & 0.112 & 0.303 & 0.115 \\
\hline $\mathrm{Cd} A \mathrm{R}$ & 0.879 & 0.152 & -0.026 & 0.176 & -0.154 \\
\hline $\mathrm{Cu} \mathrm{HCl}$ & 0.824 & -0.146 & 0.184 & -0.082 & 0.251 \\
\hline $\mathrm{Zn} \mathrm{HCl}$ & 0.852 & 0.059 & 0.123 & 0.298 & 0.149 \\
\hline $\mathrm{Cd} \mathrm{HCl}$ & 0.825 & 0.239 & -0.037 & 0.235 & -0.062 \\
\hline $\mathrm{Cu} \mathrm{NH}{ }_{4} \mathrm{Cl}$ & 0.308 & -0.116 & 0.592 & 0.090 & 0.589 \\
\hline $\mathrm{Zn} \mathrm{NH}{ }_{4} \mathrm{Cl}$ & 0.323 & -0.117 & -0.105 & 0.736 & 0.003 \\
\hline $\mathrm{Cd} \mathrm{NH} \mathrm{H}_{4} \mathrm{Cl}$ & 0.628 & 0.524 & 0.000 & 0.116 & -0.241 \\
\hline Cu soln & 0.016 & -0.153 & 0.728 & 0.262 & 0.235 \\
\hline Zn soln & 0.161 & -0.022 & -0.088 & 0.800 & 0.250 \\
\hline Cd soln & 0.116 & 0.749 & -0.037 & 0.310 & -0.152 \\
\hline $\mathrm{Cu} C_{\mathrm{E}}$ & 0.212 & -0.293 & 0.563 & 0.146 & 0.529 \\
\hline$Z n C_{E}$ & 0.257 & 0.058 & 0.031 & 0.842 & 0.160 \\
\hline $\mathrm{Cd} C_{E}$ & 0.290 & 0.801 & -0.036 & 0.126 & -0.234 \\
\hline $\mathrm{pH}$ & 0.353 & -0.732 & 0.051 & 0.228 & 0.106 \\
\hline OC & -0.114 & -0.170 & 0.768 & 0.145 & 0.203 \\
\hline CEC & 0.256 & 0.106 & 0.834 & -0.088 & -0.111 \\
\hline Cu carrot & 0.167 & 0.036 & 0.661 & 0.258 & 0.396 \\
\hline Zn carrot & 0.028 & 0.139 & 0.235 & 0.836 & -0.039 \\
\hline Cd carrot & 0.081 & 0.882 & -0.077 & 0.027 & 0.132 \\
\hline Cu onion & 0.270 & -0.010 & 0.313 & 0.348 & 0.601 \\
\hline Zn onion & 0.182 & 0.180 & 0.468 & 0.723 & 0.103 \\
\hline Cd onion & 0.104 & 0.660 & -0.273 & 0.278 & 0.275 \\
\hline Cu garlic & 0.003 & 0.203 & 0.221 & 0.285 & 0.715 \\
\hline Zn garlic & 0.331 & 0.193 & 0.293 & 0.686 & 0.193 \\
\hline Cd garlic & 0.143 & 0.770 & 0.144 & -0.033 & 0.199 \\
\hline Explained variance \% & 34.2 & 18.5 & 11.6 & 9.4 & 4.5 \\
\hline
\end{tabular}

Note. The highest loadings are in boldface type.
$\mathrm{Cd}$ and its accumulation in vegetables as suggested by $\mathrm{C}_{\text {soln }}, C_{E}$, and $\mathrm{Cd}$ in roots of all analysed vegetables along with the negative loading of $\mathrm{pH}$. Thus pseudo-total and acid extractable contents were found to be non effective for the prediction of $\mathrm{Cd}$ accumulation in plants. Our results are in agreement with other studies [27-29] that reported good correlation between bioavailable $\mathrm{Cd}$ in soil measured by DGT and its accumulation in several plant species. However, in other studies this correlation was not observed [12,30]. Although, due to their similar chemistry, it was expected that $\mathrm{Cd}$ and $\mathrm{Zn}$ would have the same behaviour in soil plant system, but only in case of $\mathrm{Cd}$, the metal content in vegetables were negatively correlated to soil pH. A possible explanation could be the easier soilplant transfer of $\mathrm{Cd}$ by binding to enzymes when the $\mathrm{Cd}$ and $\mathrm{Zn}$ enter simultaneously in the vegetable cells [24]. Our results were well in line with those obtained by Wang et al. [31] that reported stronger negative correlations between the soil $\mathrm{pH}$ and the metal accumulated in plant roots for $\mathrm{Cd}$ than for other elements.

The third PC explains about $11.6 \%$ of the variability and is determined by the $C_{\text {soln }}$ and $C_{E}$ of $\mathrm{Cu}$, positively correlated with the $\mathrm{OC}, \mathrm{CEC}$ and $\mathrm{Cu}$ accumulated in carrot roots. Positive, but less correlated appear to be the bioavailable fractions estimated by $\mathrm{NH}_{4} \mathrm{Cl}$ extraction of $\mathrm{Cu}$ in soil. The association of $\mathrm{Cu}$ in soil solution with soil OC can be explained by the strong complexes formed with dissolved organic carbon [32]. Moreover dissolved organic carbon acts as a major driver of $\mathrm{Cu}$ speciation in soil solution and transfer to plants [33] and is presumed that $\mathrm{Cu}$ complexes with fulvic and humic acids from soil solution can be easily uptake by some plants [34]. Our results are consistent with those reported by Wang et al. [31] who found positive correlation between soil $\mathrm{OC}$ and $\mathrm{Cu}$ accumulation in plant roots. In addition, our results confirm the lab-scale studies that found positive correlations between available $\mathrm{Cu}$ content assessed by DGT and plants uptake $[10,11,35,36]$, although there are other studies indicated that DGT is less effective in $\mathrm{Cu}$ bioavailability prediction [4].

The fourth PC exhibits $9.4 \%$ of the total variability, with positive loadings on bioavailable $\mathrm{Zn}$ fractions $C_{\text {soln }}$, $C_{E}, C_{N H 4 C l}$, and $\mathrm{Zn}$ accumulated in roots of all vegetable species, indicating the correlations between $\mathrm{Zn}$ available fractions and their bioaccumulation in the plant roots. Also, the lack of correlation among the pseudo-total and acid extractable $\mathrm{Zn}$ contents with $\mathrm{Zn}$ accumulation in plants was observed. The strong positive correlations between $C_{E}$ and plants uptake of Zn observed in our study is confirmed by previous pot experiment studies [4,12,36,37].

The last PC ( $4.5 \%$ variability) is influenced by $\mathrm{Cu}$ contents accumulated in roots of onion and garlic that are positively correlated with $\mathrm{Cu}$ extracted by $\mathrm{NH}_{4} \mathrm{Cl}$ and $\mathrm{Cu} C_{E}$. 
As presented in Figure 1, the 27 variables were grouped into 3 statistically significant clusters with a dissimilarity of $75 \%$. The cluster $\mathrm{C} 1$ is separated in two sub-clusters: the first sub-cluster groups $\mathrm{Zn}$ bioavailable concentrations $\left(C_{N H 4 C l}, C_{\text {soln }}, C_{E}\right)$ and $\mathrm{Zn}$ accumulated in vegetable roots, while the second sub-cluster contains $\mathrm{Cu}$ available concentrations $\left(C_{\mathrm{NH} 4 \mathrm{Cl}}, C_{\text {soln }}\right.$, and $\left.C_{E}\right)$ and $\mathrm{Cu}$ accumulated in vegetable roots along with the soil $\mathrm{pH}, \mathrm{OC}$ and $\mathrm{CEC}$. Cluster 2 includes $\mathrm{Cd}$ in bioavailable forms $\left(C_{\text {soln }}, C_{E}\right)$ and $C d$ in vegetable roots suggesting that for the prediction of $\mathrm{Cd}$ uptake by vegetables $C_{\text {soln }}$ and $C_{E}$ are more suitable than chemical extractions. The third cluster contains aqua regia and $\mathrm{HCl}$ extractable content of the three metals and $\mathrm{Cd}$ extracted in $\mathrm{NH}_{4} \mathrm{Cl}$ indicating the strong correlations among these extraction methods, but without clear indication of metals availabilities for plants.

This study is one of the first applications of DGT technique in assessing metals phytoavailability in field conditions, in moderately contaminated soils. The multivariate statistics (PCA and AHC) were used to find the relationships between metals bioavailability in soils assessed using DGT technique and chemical extractions and metals accumulation in plants and to reveal the specific behaviour of metals in soil root system. Even if the relationship between effective concentrations $\left(C_{E}\right)$ of metals were not quantitatively related to accumulation in vegetables, the correlations between the two variables were generally stronger than between metals in vegetables and in soil determined by single extraction methods.

\section{Conclusions}

This study represents the first attempt to identify relationships between the availability of $\mathrm{Cu}, \mathrm{Zn}$ and $\mathrm{Cd}$ assessed using DGT technique and several representative extractions procedures (aqua regia, diluted strong acid, neutral salt solution, soil solution) and theirs bioaccumulation in food vegetables using multivariate statistical approaches. Usually, to compare the effectiveness of extraction methods for the bioavailability prediction univariate statistics were applied. The new approach can offer supplementary information for the general characterization of the site for risk assessment purposes. Also, since DGT was used generally for the evaluation of metals bioavailability in pot experiments this study represent one of the first application of this technique under field conditions. The results obtained in this study showed that $C_{E}$, even if do not offer quantitative information on metals transfer from soil to vegetables, is effective for the general evaluation of the risks associated to toxic metals in soils. Metals concentrations assessed by aqua regia or by diluted acid $(\mathrm{HCl})$ extractions are not good predictors for metals accumulation in vegetables for the studied metals. Generally, the extraction in $\mathrm{NH}_{4} \mathrm{Cl}$ was more effective for metals bioavailability estimations than acid extractions, except for the prediction of $\mathrm{Cd}$ uptake in garlic and onion. $\mathrm{Cu}$ transfer to vegetables, especially in carrots, was found to be strongly influenced by soil OC and $\mathrm{CEC}$ than $\mathrm{Cd}$ or $\mathrm{Zn}$, while $\mathrm{pH}$ has a higher influence on $\mathrm{Cd}$ transfer to vegetables than on the other studied metals. Despite the relatively high total metal concentrations in soils, their concentrations in soil solution and effective concentrations in soil were considerably lower, thus the metals contents in roots of vegetables were similar to those typically found in agricultural crops. Although future studies on different types of soils and vegetable species or on soil sampling procedures in field conditions are necessary, the effective concentrations can satisfactorily assess metals bioavailability in soils, even in field conditions.

\section{Methods}

Site description, soil and vegetable sampling

Soils and vegetables were sampled from private gardens used by locals for growing edible vegetables from three

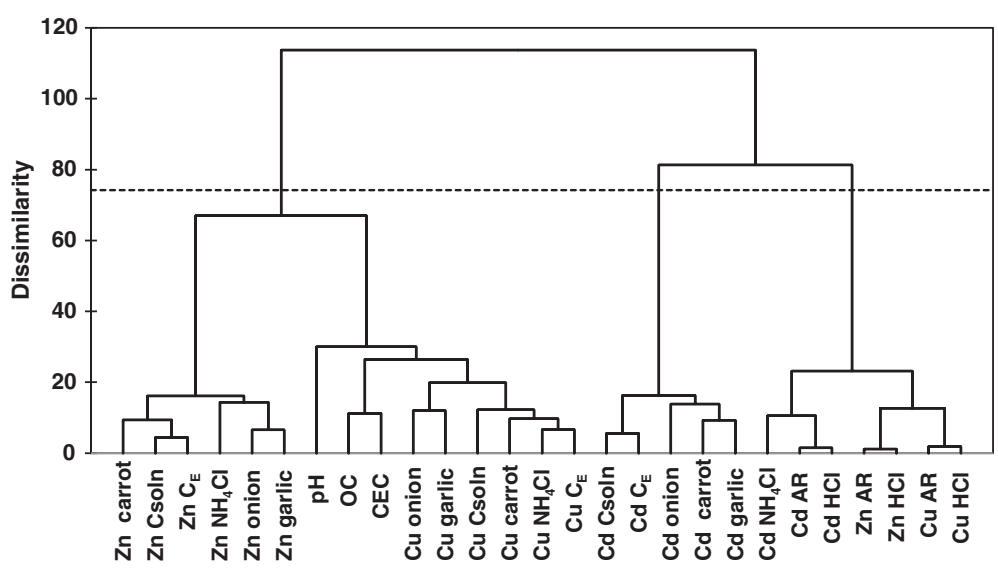

Figure 1 Dendogram showing the clustering of trace metals and physicochemical soil properties. Legend. $C_{E}-$ effective concentration; OC - organic carbon; CEC - cation exchange capacity, AR - aqua regia (pseudo-total concentration), Csoln - concentration in soil solution. 
small villages: Bozanta Mare (BM: samples 1-10); Sasar (SA: samples 11-20); and Recea (RC: samples 21-30), in summer of 2011. The villages are located near three tailing deposits resulted from the ore processing activities from Baia Mare, North-West Romania, an area with a longhistory of non-ferrous ore mining and processing $[18,26]$. As presented in Figure 2, the study area is located between $23^{\circ} 24^{\prime}-23^{\circ} 30^{\prime}$ Est longitude and 47 $36^{\prime}-47^{\circ} 39^{\prime}$ North latitude.

Ten sampling points were randomly selected in each village based on the distribution of the existing gardens. Three common vegetables: Carrot (Daucus carota), Onion (Allium cepa L.) and Garlic (Allium sativum L.) were collected in 7-10 week growth period. In order to assure the comparability of the results, only the roots (considered edible parts) of the plants were used in the assessment study. In each sampling point three specimens of each vegetable species were randomly sampled, then intensely rinsed with tap water and distilled water and stored in polyethylene bags. Once the vegetables removed from the ground, soil samples adhering to their roots and underneath them were sampled. In the lab, the soils were spread over a polyethylene sheet, air-dried at room temperature for one week and sieved through a $2-\mathrm{mm}$ nylon mesh. The vegetable roots were rinsed using $1 \mathrm{M} \mathrm{HCl}$, followed by ultrapure water and then dried at $40^{\circ} \mathrm{C}$, grounded and sieved through $100-\mu \mathrm{m}$ nylon mesh. All the soil and vegetable samples were kept in closed plastic bags until analysis.

\section{Soil and vegetable analysis}

The pseudo-total metals concentrations of soils were determined after aqua regia digestion according to ISO 11466:1995. An amount of $1 \mathrm{~g}$ of dried soil, previously grounded and passed through the $100-\mu \mathrm{m}$ nylon mesh, was heated with $28 \mathrm{~mL}$ aqua regia, then filtered through $0.45 \mu \mathrm{m}$ pore size filter and diluted to $100 \mathrm{~mL}$ with ultrapure water. Potentially available contents of metals from soil were determined by single extractions with $1 \mathrm{M}$ $\mathrm{HCl}$ (ratio $\mathrm{w} / \mathrm{v}=1: 33.3$, time $2 \mathrm{~h}$, room temperature) and $1 \mathrm{M} \mathrm{NH} \mathrm{NH}_{4} \mathrm{Cl}$ (ratio $\mathrm{w} / \mathrm{v}=1: 6$, time $16 \mathrm{~h}$, room temperature), as described by Kashem et al. [19]. For vegetables digestion, an amount of $0.5 \mathrm{~g}$ of dried sample was heated with a mixture of $2 \mathrm{~mL}$ of $\mathrm{H}_{2} \mathrm{O}_{2}$ and $6 \mathrm{~mL}$

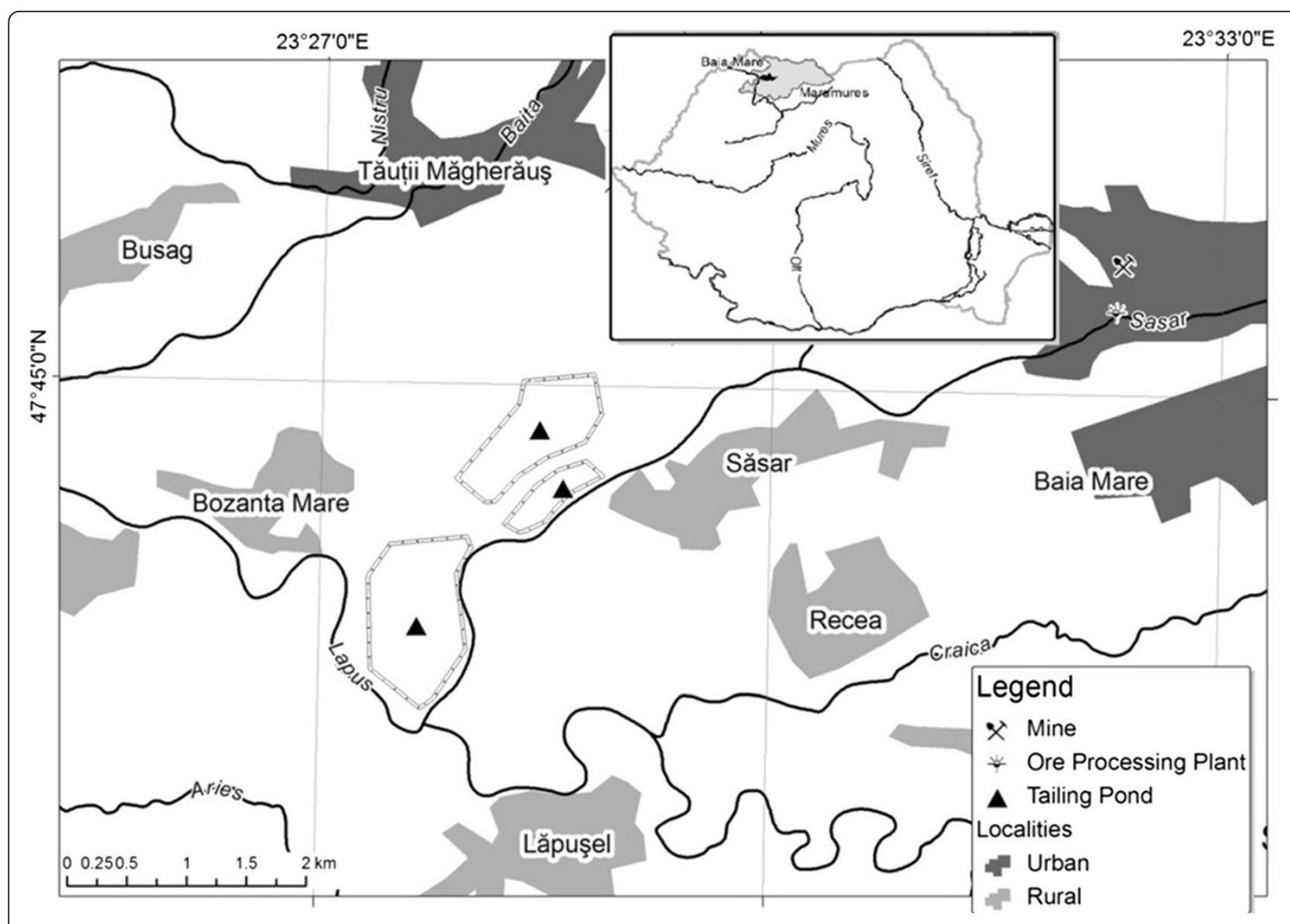

Figure 2 Schematic map of sampling sites in the Baia Mare mining area. Legend. The three sampling villages included in the study: Bozanta Mare (BM), Sasar (SA), and Recea (RC). 
$\mathrm{HNO}_{3}$ using a MWS3+ Berghoff microwave system (Eningen, Germany), then the resulting solutions were filtered and diluted to $50 \mathrm{~mL}$ with ultrapure water. The content of metals were measured by inductively coupled plasma optical emission multichannel spectrometer (ICP-OES) Optima 5300 DV (Perkin Elmer, USA) in soil extracts and by inductively coupled plasma mass spectrometer (ICP-MS), equipped with dynamic reaction cell, ELAN DRC II (Perkin Elmer, Canada) in vegetables, soil solutions and DGT extracts. Soil $\mathrm{pH}$ was measured using a JENWAY $3340 \mathrm{pH}$-meter in 1:5 (w:v) soil to water ratio, while total carbon and inorganic carbon contents were determined by dry combustion and non-dispersive infrared carbon analyzer using the Multi N/C $2100 \mathrm{~S}$ Analyser (Analytic Jena, Germany). The OC was calculated as difference between total and inorganic carbon. The CEC was calculated after ICP-OES determinations of exchangeable major cations, according to ISO 23470:2007. To measure water holding capacity (WHC), the soil was placed on a filter paper in a vessel containing water until saturation, and then the soil was allowed to drain in water-saturated atmosphere. The water content in saturated soil was determined gravimetrically [28].

Blank samples and certified reference materials (CRMs) of soil (SRM 2709 San Joaquin Soil, New York, USA) and vegetable (IAEA-359 Cabbage, Vienna, Austria) were used for the quality control of total metals determination. Recoveries for all analysed metals from soil CRM were in the range of $87.5-102 \%$, measured with precision between 4.5-12.2\% ( $n=5$ parallel samples), while the recoveries for analysed metals in vegetable CRM ranged between 91.0-104\% measured with precision ranged between $7.8-13.4 \%$ ( $n=5$ parallel samples). Reagents of analytical grade or better and ultrapure water obtained by a Milli Q system (Millipore, France) were used for the experiments.

\section{DGT and soil solution measurements}

DGT devices were purchased from DGT Research Ltd. (Lanchester, UK) and consists of a plastic base covered by a layer of Chelex-100 resin impregnated in a hydrogel to accumulate the metals that passed through the diffusive gel (open pore) layer and protected in exterior by a $0.45-\mu \mathrm{m}$ filter.

Amounts of $25 \mathrm{~g}$ of soil samples were brought to room temperature $\left(22^{\circ} \mathrm{C}\right)$, mixed with ultrapure water until $100 \% \mathrm{WHC}$, and kept for $24 \mathrm{~h}$ at $22^{\circ} \mathrm{C}$ for equilibration. The DGT devices were gently pushed into the equilibrated soil slurries, ensuring that between the edges of the container and the exposed DGT the distance is at least $2 \mathrm{~cm}$. The containers were covered with plastic films to avoid water evaporation from the soil during the DGT deployment, and kept at $22^{\circ} \mathrm{C}$ for $24 \mathrm{~h}$. For each soil sample 3 replicates were carried out. At retrieval, the devices were cleaned from the adhering soil by washing carefully with ultrapure water and dried with absorbent paper. Metals were eluted from the chelating resin with $1 \mathrm{~mL} 1 \mathrm{M} \mathrm{HNO}_{3}$ for minimum $24 \mathrm{~h}$. The eluents were diluted 5 times before metals determination by ICP-MS.

To determine the mass of a metal accumulated in the resin (M), the equation (1) was used [20]:

$$
\mathrm{M}=\mathrm{CF}\left(\mathrm{V}_{\mathrm{acid}}+\mathrm{V}_{\text {gel }}\right) / \mathrm{f}_{\mathrm{e}}
$$

where $C$ is the metal concentration in $\mathrm{HNO}_{3}$ solution measured by ICP-MS, $F$ is the dilution factor (5), $V_{\text {acid }}$ is the volume of $\mathrm{HNO}_{3}$ added to the resin $(1 \mathrm{~mL}), V_{\text {gel }}$ is the volume of resin gel $(0.15 \mathrm{~mL}), \mathrm{f}_{e}$ is the elution factor (0.8). The time averaged concentration of metal $\left(C_{D G T}\right)$ was calculated by equation 2 :

$$
\mathrm{C}_{\mathrm{DGT}}=\mathrm{M} \Delta \mathrm{g} / \mathrm{D} \mathrm{t} \mathrm{A}
$$

where $\Delta g$ is the thickness of the diffusive gel $(0.078 \mathrm{~cm})+$ membrane filter $(0.014 \mathrm{~cm}), D$ is the diffusion coefficient of the metal in the resin gel, $t$ is the deployment time (86400 sec), and $A$ is the area of the sampling window of the DGT device $\left(3.14 \mathrm{~cm}^{2}\right)$.

To measure the metals concentration in soil solution $\left(C_{\text {soln }}\right)$, a portion of the soil paste prepared for the DGT measurements was introduced in $25 \mathrm{~mL}$ polyethylene tubes and centrifuged at $5000 \mathrm{rpm}$ for 20 minutes. The collected supernatant was filtered by means of a syringe connected to a $0.45-\mu \mathrm{m}$ pore size filter. Soil solutions (3 mL) were stabilized with $10 \mu \mathrm{L}$ ultrapure $65 \% \mathrm{HNO}_{3}$ and metals concentrations were measured by ICP-MS. To measure the resupply from solid phase the ratio $(R)$ between $C_{D G T}$ and $C_{\text {soln }}$ was calculated.

The measured DGT flux of metals in the soil can be quantitatively linked to effective concentration $\left(C_{E}\right)$ that includes both soil solution concentration and its enrichment from the solid phase, and can be calculated using equation 3:

$$
\mathrm{C}_{\mathrm{E}}=\mathrm{C}_{\mathrm{DGT}} / \mathrm{R}_{\mathrm{diff}}
$$

where $R_{\text {diff }}$ is calculated using the computer numerical model 2DDIFS (2DDGT Induced Fluxes in Sediments) as described by Sochaczewski et al. [38]. The required input parameters in order to calculate $R_{\text {diff }}$ were particle concentration $\left(P_{c}\right)$, metal diffusion coefficients in water, in soil and in diffusive gels $\left(D_{O}, D_{s}, D_{d}\right)$, diffusion layer thickness $(\Delta g=0.092 \mathrm{~cm})$, deployment time $(t=24 \mathrm{~h})$. For particle density $\left(P_{s}\right)$, the typical value for mineral soils of $2.65 \mathrm{~g} \mathrm{~cm}^{-3}$ was used [39]. A large value for $T_{c}$ (soil response time) and a small value for $K_{d}$ (plant available fraction of element bound to the soil) were introduced in the input mode of 2D DIFS according to Tandy et al. [36]. $P_{c}$ was calculated using equation 4 : 


$$
\mathrm{P}_{\mathrm{c}}=\mathrm{m} / \mathrm{V}
$$

where $m$ is the mass of soil used and $V$ is the volume of water added to obtain the $100 \%$ WHC for DGT deployments.

\section{Statistical analysis}

The XLStat Microsoft Excel plug-in (Addinsoft) was used for the statistical processing of the data. Principal Component Analysis (PCA) with varimax rotation was used to interpret the structure of the main dataset. Agglomerative Hierarchical Clustering (AHC) using the Ward's linkage method and Euclidian distances as a measure of similarity was used to group the determined parameters into classes.

\section{Competing interests}

The authors declare that they have no competing interests.

\section{Authors' contributions}

MS organized the experimental setting, collected the samples, performed metals determinations, including DGT and chemical extractions, interpreted the results and wrote the manuscript. EAL performed $O C$ analyses and helped at chemical extraction, statistical analysis and manuscript preparation. LRS performed CEC analyses, helped at DGT determinations and manuscript preparation. All authors read and approved the final manuscript.

\section{Acknowledgements}

This work was supported by Romanian financing authority CNCS -UEFISCDI, Human Resources, project number PN-II-RU-PD-2011-3-0050.

\section{Received: 6 September 2012 Accepted: 17 October 2012}

Published: 18 October 2012

\section{References}

1. Gal J, Markiewicz-Patkowska J, Hursthouse A, Tatner P: Metal uptake by woodlice in urban soils. Ecotox Environ Safe 2008, 69:139-149.

2. Harmanescu M, Alda LM, Bordean DM, Gogoasa I, Gergen I: Heavy metals health risk assessment for population via consumption of vegetables grown in old mining area; a case study: Banat County, Romania. Chem Cent J 2011, 5:64.

3. Malizia D, Giuliano A, Ortaggi G, Masotti A: Common plants as alternative analytical tools to monitor heavy metals in soil. Chem Cent J 2012, 6:S6.

4. Ahumada I, Ascar L, Pedraza C, Vasquez V, Carrasco A, Richter P, Brown S: Determination of the bioavailable fraction of $\mathrm{Cu}$ and $\mathrm{Zn}$ in soils amended with biosolids as determined by diffusive gradients in thin films (DGT), BCR sequential extraction, and ryegrass plant. Water Air Soil Poll 2011, 219:225-237.

5. Kaplan O, Ince M, Yaman M: Sequential extraction of cadmium in different soil phases and plant parts from a former industrialized area. Environ Chem Lett 2011, 9:397-404.

6. Senila M, Levei E, Miclean M, Senila L, Stefanescu L, Marginean S, Ozunu A, Roman C: Influence of pollution level on heavy metals mobility in soil from NW Romania. Environ Eng Manag J 2011, 10:59-64.

7. Zhang H, Davison W, Knight B, McGrath S: In situ measurement of solution concentrations and fluxes of trace metals in soils using DGT. Environ Sci Technol 1998, 32:704-710.

8. Davison $\mathrm{W}$, Zhang $\mathrm{H}$ : In situ speciation measurements of trace components in natural waters using thin-film gels. Nature 1994, 367:546-548.

9. Odzak N, Kistler $D$, Xue $H$, Sigg L: In situ trace metal speciation in a eutrophic lake using the technique of diffusion gradients in thin films (DGT). Aquat Sci 2002, 64:292-299.
10. Zhang H, Zhao FJ, Sun B, Davison W, McGrath S: A new method to measure effective soil solution concentration predicts copper availability to plants. Environ Sci Technol 2001, 35:2602-2607.

11. Nowack B, Koehler S, Schulin R: Use of diffusive gradients in thin films (DGT) in undisturbed field soils. Environ Sci Technol 2004, 38:1133-1138.

12. Soriano-Disla JM, Speir TW, Gomez I, Clucas LM, McLaren RG, NavarroPedreno J: Evaluation of different extraction methods for the assessment of heavy metal bioavailability in various soils. Water Air Soil Poll 2010, 213:471-483.

13. Koster M, Reijnders L, van Oost NR, Peijnenburg WJGM: Comparison of the method of diffusive gels in thin films with conventional extraction techniques for evaluating zinc accumulation in plants and isopods. Environ Pollut 2005, 133:103-116.

14. Cattani I, Fragoulis G, Boccelli R, Capri E: Copper bioavailability in the rhizosphere of maize (Zea mays L.) grown in two Italian soils. Chemosphere 2006, 64:1972-1979.

15. Bravin MN, Michaud AM, Larabi B, Hinsinger P: RHIZOtest: A plant-based biotest to account for rhizosphere processes when assessing copper bioavailability. Environ Pollut 2010, 158:3330-3337.

16. Kabata-Pendias A, Mukherjee AB: Trace elements from soil to human. New York: Springer; 2007.

17. Lacatusu R, Lacatusu A, Lungu M, Breaban I: Macro- and microelements abundance in some urban soils from Romania. Carpath J Earth Env 2008, 3:75-83

18. Levei E, Frentiu T, Ponta M, Senila M, Miclean M, Roman C, Cordos E: Characterization of soil quality and mobility of $\mathrm{Cd}, \mathrm{Cu}, \mathrm{Pb}$ and $\mathrm{Zn}$ in the Baia Mare area Northwest Romania following the historical pollution. Int J Environ An Ch 2009, 89:635-649.

19. Kashem MA, Singh BR, Kondo T, Imamul Huq SM, Kawai S: Comparison of extractability of $\mathrm{Cd}, \mathrm{Cu}, \mathrm{Pb}$ and $\mathrm{Zn}$ with sequential extraction in contaminated and non-contaminated soils. Int J Environ Sci Technol 2007, 4:169-176.

20. DGT Research Ltd Lancaster, UK: DGT-for measurements in waters, soils and sediments. Available at: www.dgtresearch.com, Accessed: 27 May 2011.

21. Ruello ML, Sileno M, Sani D, Fava G: DGT use in contaminated site characterization. The importance of heavy metal site specific behavior. Chemosphere 2008, 70:1135-1140.

22. Nagajyoti PC, Lee KD, Sreekanth TVM: Heavy metals, occurrence and toxicity for plants: a review. Environ Chem Lett 2010, 8:199-216.

23. Liu HY, Probst A, Liao B: Metal contamination of soils and crops affected by the Chenzhou lead zinc mine spill (Hunan, China). Sci Total Environ 2005, 339:153-166.

24. Zhuang P, McBride MB, Xia H, Li N, Li Z: Health risk from heavy metals via consumption of food crops in the vicinity of Dabaoshan mine, South China. Sci Total Environ 2009, 407:1551-1561.

25. Miclean M, Levei E, Senila M, Roman C, Cordos E: Assessment of Cu, Pb, Zn and $\mathrm{Cd}$ availability to vegetable species grown in the vicinity of tailing deposits from Baia Mare area. Rev Chim-Bucharest 2009, 60:1-4.

26. Senila M, Levei E, Senila L, Oprea G, Roman C: Mercury in soil and perennial plants in a mining-affected urban area from Northwestern Romania. J Environ Sci Heal A 2012, 47:614-621.

27. Perez AL, Anderson KA: DGT estimates cadmium accumulation in wheat and potato from phosphate fertilizer applications. Sci Total Environ 2009, 407:5096-5103.

28. Muhammad I, Puschenreiter M, Wenzel WW: Cadmium and Zn availability as affected by $\mathrm{pH}$ manipulation and its assessment by soil extraction, DGT and indicator plants. Sci Total Environ 2012, 416:490-500.

29. Garcia-Salgado S, Garcia-Casillas D, Quijano-Nieto MA, Bonilla-Simon MM: Arsenic and heavy metal uptake and accumulation in native plant species from soils polluted by mining activities. Water Air Soil Pollut 2012, 223:559-572.

30. Agbenin JO, Welp G: Bioavailability of copper, cadmium, zinc, and lead in tropical savanna soils assessed by diffusive gradient in thin films (DGT) and ion exchange resin membranes. Environ Monit Assess 2012, 184:2275-2284.

31. Wang XP, Shan XQ, Zhang SZ, Wen B: A model for evaluation of the phytoavailability of trace elements to vegetables under the field conditions. Chemosphere 2004, 55:811-822

32. Kovarikova V, Docekalova H, Docekal B, Podborska M: Use of the diffusive gradients in thin films technique (DGT) with various diffusive gels for 
characterization of sewage sludge-contaminated soils. Anal Bioanal Chem 2007, 389:2303-2311.

33. Bravin MN, Marti AL, Clairotte M, Hinsinger P: Rhizosphere alkalisation - a major driver of copper bioavailability over a broad $\mathrm{pH}$ range in an acidic, copper-contaminated soil. Plant Soil 2009, 318:257-268.

34. Krishnamurti GSR, Naidu R: Solid-solution speciation and phytoavailability of copper and zinc in soils. Environ Sci Technol 2002, 36:2645-2651.

35. Tian Y, Wang XR, Luo J, Yu HX, Zhang H: Evaluation of holistic approaches to predicting the concentrations of metals in field-cultivated rice. Environ Sci Technol 2008, 42:7649-7654.

36. Tandy S, Mundus S, Yngvesson J, de Bang TC, Lombi E, Schjoerring JK, Husted S: The use of DGT for prediction of plant available copper, zinc and phosphorus in agricultural soils. Plant Soil 2011, 346:167-180.

37. Almas AR, Lombnaes P, Sogn TA, Mulder J: Speciation of Cd and Zn in contaminated soils assessed by DGT-DIFS, and WHAM/Model VI in relation to uptake by spinach and ryegrass. Chemosphere 2006, 62:1647-1655.

38. Sochaczewski L, Tych W, Davison B, Zhang H: 2D DGT induced fluxes in sediments and soils (2D DIFS). Environ Modell Softw 2007, 22:14-23.

39. Mihalik J, Henner P, Frelon S, Camilleri V, Fevrier L: Citrate assisted phytoextraction of uranium by sunflowers: Study of fluxes in soils and plants and resulting intra-planta distribution of Fe and U. Environ Exp Bot 2012, 77:249-258.

doi:10.1186/1752-153X-6-119

Cite this article as: Senila et al:: Assessment of metals bioavailability to vegetables under field conditions using DGT, single extractions and multivariate statistics. Chemistry Central Journal 2012 6:119.

\section{Publish with ChemistryCentral and every scientist can read your work free of charge \\ "Open access provides opportunities to our colleagues in other parts of the globe, by allowing anyone to view the content free of charge." \\ W. Jeffery Hurst, The Hershey Company. \\ - available free of charge to the entire scientific community \\ - peer reviewed and published immediately upon acceptance \\ - cited in PubMed and archived on PubMed Central \\ - yours - you keep the copyright \\ Submit your manuscript here: \\ http://www.chemistrycentral.com/manuscript/<smiles>c1ccccc1</smiles> \\ Chemistry Central}

